\title{
Natural Openness and Good Government
}

\author{
Shang-Jin Wei \\ CID Working Paper No. 61 \\ February 2001
}

(C) Copyright 2001 Shang-Jin Wei and the President and Fellows of Harvard College

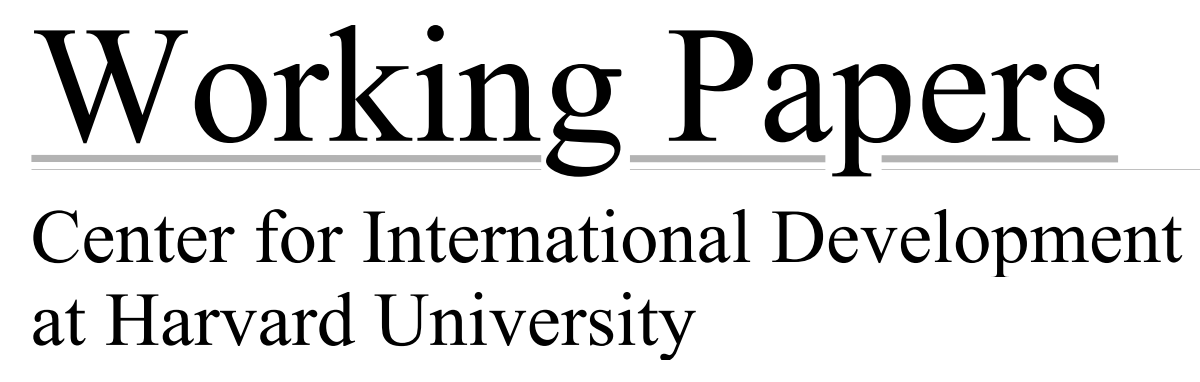




\title{
Natural Openness and Good Government
}

\author{
Shang-Jin Wei
}

\begin{abstract}
This paper offers a possibly new interpretation of the connection between openness and good governance. Assuming that corruption and bad governance drive out international trade and investment more than domestic trade and investment, a "naturally more open economy" -- as determined by its size and geography -- would devote more resources to building good institutions and would display lower corruption in equilibrium. In the data, "naturally more open economies" do exhibit less corruption even after taking into account their levels of development. "Residual openness" -- which potentially includes trade policies -- is found not to be important once "natural openness" is accounted for. Moreover, "naturally more open economies" also tend to pay better civil servant salaries relative to their private sector alternatives -- indicative of the marginal benefit of good governance in a society's revealed preference. These patterns are consistent with the conceptual model.
\end{abstract}

Keywords: natural openness, corruption.

Shang-Jin Wei is a Faculty Associate at The Center for International Development at Harvard University, Associate Professor of Public Policy, at the Kennedy School of Government, a Faculty Research Fellow at the National Bureau of Economic Research, Senior Fellow at the Brookings Institution, and Advisor, The World Bank.

Email:swei@brook.edu

I thank Yi Wu for superb research assistance, Roberta Gatti and Caroline van Rijckeghem for sharing their data, and Chong-En Bai, Roberta Gatti, David Parsley, Dani Rodrik, Caroline van Rijckeghem, and seminar participants at the World Bank for helpful discussion. 


\title{
Natural Openness and Good Government
}

\author{
Shang-Jin Wei
}

\section{Introduction}

The quality of government and level of bureaucratic corruption vary widely across countries. Several authors have documented that more open countries tend to have a lower level of corruption (Ades and Di Tella, 1999; Treisman, 1998; and Gatti, 1999).

This association has been understood in one of the two ways. First, more open trade policies induce greater competition which helps to reduce corruption. Second, in a reverse direction, corrupt bureaucrats like to set up trade barriers to extract bribes, reducing openness as a consequence. Both stories can be relevant in reality.

This paper offers a different interpretation of the connection between openness and corruption. It argues that a country's "natural openness", as determined by its geography and size, affects a country's incentive in investing in corruption-fighting public governance infrastructure. The central logic is as follows. Fighting corruption and investing in good governance is costly. Since international traders and investors are more footloose (i.e., have better outside options) than domestic ones, bad governance and bureaucratic corruption in a country reduces international trade and investment more than domestic trade and investment ${ }^{\square}$ A country that is naturally more open - as determined by its size, geography and other factors would find it optimal to devote more resources to building good institutions. In equilibrium, such economies may display less corruption and a higher quality of government than naturally less open economies.

The main body of the paper examines the relevance of this hypothesis in the data. In terms of our empirical strategy, the closest precursor is Frankel and Romer (1999), who constructed a measure of "natural openness" (though they didn't use the term) and related it to income levels across countries. Indeed, our paper may offer some new insight into the openness-

\footnotetext{
${ }^{1}$ Wei (2000) concludes that foreign investors are very averse to corruption: a rise in corruption from a level that prevails in Singapore (i.e., low) to a level that prevails in Mexico (i.e., high) has the same negative effect on inward foreign direct investment as raising the marginal tax rate by fifty percentage points! Tamirisa and Wei (2000) show that corruption also deters international trade significantly. That is, corruption acts more like a non-tariff barrier than as a lubricant to international trade.
} 
growth connection that they examined: it is possible that naturally more open economies grow faster in part because they also invest more in building good public governance and fighting corruption.

We examine two different indicators of public governance. The first is an output indicator, namely the level of bureaucratic corruption. The second is an input indicator, namely, public sector salaries relative to their private sector alternatives. We show that a measure of 'natural openness' based on countries' size, geography and linguistics, is a significant explanatory variable for the different levels of corruption across countries. 'Residual opennes' i.e., the difference between the trade-to-GDP ratio and the "natural openness" - which potentially includes trade policies - is often not significant statistically once 'natural openness' is accounted for.

Van Rijckeghem and Weder (1999) reported evidence that a country with a higher public sector salary (relative to their private sector opportunity) tends to have lower corruption. Here, we show that in the data, a naturally more open economy tends to pay a better relative salary to its civil servants (even after controlling for the level of development of the country). These patterns are consistent with our theoretical story.

The paper is organized as follows. In Section 2, we describe a simple story that suggests a causal relationship from natural openness to quality of government. In Section 3, we go to the data, examining the relationship between a measure of natural openness and several different measures of the quality of public governance. Section 4 provides some concluding remarks.

\section{A Simple Theory}

While this paper is primarily empirical in nature, we provide a minimalist model that formalizes the idea discussed above and can serve as a guide to the subsequent statistical analyses.

\subsection{Benchmark model}

\section{$\underline{\text { Structure of the world }}$}

There are two countries, a "Home" country, H, and "the rest of the world," W. Both countries are in the shape of a sphere where people are uniformly distributed. There are n people in 
"Home" and m people in the "rest of the world." The radiuses of the two spheres are r/2 and $\mathrm{R} / 2$, respectively. In the middle of each country, there is a "hub." Within country "home", trade between any two persons must go through the hub. Thus, the distance between any two persons within country $\mathrm{H}$ is $\mathrm{r}$. For any person in Country $\mathrm{H}$ to trade with another person in Country W, they have to go through their respective hubs. Assuming the distance between the two hubs are $\mathrm{D}-\mathrm{r} / 2-\mathrm{R} / 2$, then the distance between domestic and foreign residents is always $\mathrm{D}$.

See Figure 1.

\section{Setup of the model}

There are two periods. In period one, people in Country $\mathrm{H}$ decide how much to invest to build good public institutions (that would reduce the incidence of bureaucratic corruption). In period zero, people are randomly matched into pairs to realize joint production. The matching can take place either between two people from the same country or from different countries ${ }^{\square}$.

Consider a representative agent $\mathrm{j}$ in Country $\mathrm{H}$. Use $\mathrm{k}$ to index the partner with whom $\mathrm{j}$ is randomly matched, and denote the distance between $\mathrm{j}$ and $\mathrm{k}$ by $\mathrm{D}_{\mathrm{j}}(\mathrm{k})$.

$$
\begin{aligned}
\mathrm{D}_{\mathrm{j}}(\mathrm{k}) & =\mathrm{r} & & \text { if } \mathrm{k} \in \mathrm{H} \\
& =\mathrm{D} & & \text { if } \mathrm{k} \in \mathrm{W}
\end{aligned}
$$

The ratio of the two distances, $\mathrm{D} / \mathrm{r}$, measures the relative remoteness of country "Home" from the rest of the world market, which is one aspect of "natural openness."

In period one, the expected utility for agent $\mathrm{j}$ is

$$
E U_{j}=E Y_{j}-t_{j}
$$

Where $t_{j}$ is the amount of tax $\mathrm{j}$ has to pay in period one to build up public institutions, and $\mathrm{Y}$ is output. Without loss of generality, we assume no discounting.

The output level from the random matching depends on who the joint venture partner is 


$$
\begin{aligned}
\mathrm{Y}_{\mathrm{j}}(\mathrm{k}) & = & \mathrm{x}-\mathrm{C}_{\mathrm{h}} & \text { if } \mathrm{k} \in \mathrm{H} \\
& = & \mathrm{x}-(1+\theta) \mathrm{C}_{\mathrm{h}} & \text { if } \mathrm{k} \in \mathrm{W}
\end{aligned}
$$

where $\mathrm{x}$ is an exogenous level output from the joint venture if there were no corruption, $\mathrm{C}_{\mathrm{h}}=$ the level of corruption in Country $\mathrm{H}$, and $\theta>0$ indicating that a given level of corruption has a larger negative impact on international production/trade than domestic production/trade. This is a representation of the idea that corruption reduces international business more than domestic business. One way to think of this is through a bargaining framework. Because international investors/traders have better outsider options (they can choose to do business in a different country), domestic agent $\mathrm{j}$ has to concede a bigger share of the output to an international partner than a domestic one, and be content with a smaller share for herself. An alternative way to justify this is through a story of costly contract enforcement. There is more "trust" between two domestic partners than between an international and a domestic partner, possibly because other informal, cultural, tribal institutions exist for the former but not for the latter. Business transactions involving international partners involves more costly contracting than those with domestic partners.

Let $\mathrm{P}(\mathrm{k} \in \mathrm{W})$ denote the probability that $\mathrm{j}$ would be matched with someone from the world market, and recall that $\mathrm{n} / \mathrm{m}$ is the population size of country "Home" relative to the rest of the world. We assume that

$\mathrm{P}(\mathrm{k} \in \mathrm{W})=\mathrm{f}(\mathrm{D} / \mathrm{r}, \mathrm{n} / \mathrm{m})$

with $\mathrm{f}_{1}<0$ and $\mathrm{f}_{2}<0$. In other words, a country that is far away from the rest of the world, or one that has a relatively large domestic market, is less likely to engage in international economic activities. $\mathrm{P}(\mathrm{k} \ni \mathrm{W})$ describes the opportunity for residents in Country $\mathrm{H}$ to interact with international traders/investors, which will turn out to be a key to our results. We label $\mathrm{P}(\mathrm{k} \in \mathrm{W})$ or $\mathrm{f}($.$) as an index of "natural openness" for the country in question. Of course, the probability$

\footnotetext{
${ }^{2}$ Without random matching, an alternative but more complicated specification would be to let everyone (domestic and foreign) have a utility function over differentiated goods but be endowed with one good, and let corruption to raise the cost on international trade more than on domestic trade. This would generate similar results.
} 
that people in country "home" trade with other people in the same country is just the complement of the "natural openness": $\mathrm{P}(\mathrm{k} \in \mathrm{H})=1-\mathrm{P}(\mathrm{k} \in \mathrm{W})$.

Therefore, the expected utility in Period two for representative agent $\mathrm{j}$ is just expected output minus tax:

$E U(j)=\left[x-(1+\theta) C_{h}\right] P(k \in W)+\left(x-C_{h}\right)[1-P(k \in W)]-t$

The level of corruption in Country $\mathrm{H}, \mathrm{C}_{\mathrm{h}}$, depends negatively on how much resources Country $\mathrm{H}$ devotes to fighting corruption. These costs are an increasing and convex function. In other words, as a country puts in more and more resources into fighting corruption, corruption decreases but at a slower rate. More precisely, we assume that relationship between the level of corruption and the level of per capita tax is given by the following relationship:

$\mathrm{C}_{\mathrm{h}}=\mathrm{C}(\mathrm{t})$ where $\mathrm{C}^{\prime}<0$ and $\mathrm{C}^{\prime}>0$.

Note that we assume that the level of tax per capita needed to achieve a given level of corruption is independent of the country size. This assumption is made for simplification. As the size of a country gets larger, there are two opposing forces impacting these costs on a per capita basis. First, greater size may be conducive to more layers of bureaucracy, making it more costly to monitor the behavior/performance of the entire bureaucracy. So a larger amount of resources may be needed to get a given quality of bureaucracy. On the other hand, there are more people contributing to the budget, so the per capita tax requirement is smaller for a given budget. The net effect of these two forces determines whether the per capita cost of achieving a given level of bureaucracy should increase or decrease with the size of the country. Since we do not have a good basis to make one assumption versus the other, we do not wish to take a stand in this paper on this issue. Instead, we assume that the amount of tax per capita is always the same for a given level of quality of bureaucracy (or a given level of corruption). In other words, for a given level of tax per capita, quality of bureaucracy is invariant to country size.

In period one, representative agent $j$ chooses an optimal amount of investment $t_{j}$ to devote to public institution building in order to maximize her expected utility.

The first order condition of this maximization problem is 
$(1+\theta) \mathrm{f} \mathrm{C}^{\prime}+(1-\mathrm{f}) \mathrm{C}^{\prime}+1=0$

Given the convexity of the $\mathrm{C}(\mathrm{t})$ function, it is easy to verify that the second order condition is satisfied.

This defines an implicit function for optimal amount of tax the representative agent desires: $\mathrm{t}=\mathrm{t}[\mathrm{f}, \theta]$.

Proposition 1: Optimal tax, $\mathrm{t}$, (or equilibrium corruption, $\mathrm{C}$ ) is an increasing (or a decreasing) function of natural openness, $\mathrm{f}$.

Proof: By totally differentiating the first order condition and re-arranging the terms, we obtain

$\frac{d t}{d f}=-\frac{\theta C^{\prime}(.)}{(\theta f+1) C^{\prime \prime}(.)}>0$

Making use of the assumption on the corruption-control equation, $\mathrm{C}=\mathrm{C}(\mathrm{t})$, we have $\frac{d C_{h}}{d f}=C^{\prime}(.) \frac{d t}{d f}<0$

Hence, naturally more open economies find it optimal to devote more resources in building public institutions to fight corruption. This would translate into a lower level of corruption in equilibrium.

\subsection{Extensions: Heterogeneity and Political Economy}

So far, we have assumed that everyone in the country is identical. Here, we explore some implications of heterogeneity among people for public institution building. We assume that the resources devoted to fighting corruption are determined by majority voting. We keep heterogeneity in one-dimension so that median voter decides the outcome of the voting. We 
assume further that the actual tax rate is the same across all individuals (even though the desired level of tax could be different).

Suppose now that the output level for agent $j$ in country "Home" (from the random matching production process) depends on individual characteristics of $j$ as well as on who the joint venture partner is.

$$
\begin{aligned}
Y_{j}(k) & = & x(j)-z(j) C_{h} & \text { if } k \in H \\
& =\quad x(j)-[1+\theta(j)] z(j) C_{h} & & \text { if } k \in W
\end{aligned}
$$

where $\mathrm{z}(\mathrm{j})$ is some positive parameter.

In other words, relative to the benchmark model, we now let income, $x(j)$, the effect of corruption on output, $z(j)$, and the extra effect of corruption on international transactions, $\theta(j)$, to be indexed by $\mathrm{j}$.

The rest of the model is unchanged. To find out individual $\mathrm{j}$ 's desired level of tax (to be used to build public institutions), she still solves the same optimization as before, namely, choose $t(j)$ in order to maximize

$E U(j)=\left[x(j)-(1+\theta(j)) z(j) C_{h}\right] P(k \in W)+\left[x(j)-z(j) C_{h}\right][1-P(k \in W)]-t(j)$

The first order condition of this maximization problem is

$[1+\theta(j)] z(j) f n C^{\prime}[t(j)]+(1-f) z(j) C^{\prime}[t(j)]+1=0$

Or

$\{[f \theta(j)+1] z(j)\} C^{\prime}(t)+1=0$

Agent j's desired level of tax, $t(j)$, is given by the implicit function implied by the first order condition:

$t^{*}(j)=t[f \theta(j), z(j)]$ 
It is easy to verify the following proposition by totally differentiating the first order condition.

\section{Proposition 2:}

(i) The desired level of tax by j increases with "natural openness";

$$
\frac{d t(j)}{d f}=-\frac{\theta(j) C^{\prime}(.)}{[\theta(j) f+1] C^{\prime \prime}(.)}>0
$$

(ii) The desired tax increases with the elasticity of output loss due to corruption;

$$
\frac{d t(j)}{d z(j)}=-\frac{C^{\prime}(.)}{z(j) C^{\prime \prime}(.)}>0
$$

(iii) The desired tax increases with the extra effect of corruption on international transactions, $\theta(\mathrm{j})$;

$$
\frac{d t(j)}{d \theta(j)}=-\frac{f C^{\prime}(.)}{[\theta(j) f+1] C^{\prime \prime}(.)}>0 .
$$

When agents are heterogeneous, the tax level desired by different agents are also different. In particular, the equilibrium tax desired by the median voter (which decides the political outcome) may be different from what is desired by the average voter (which maximizes the social welfare function that assigns equal weights to everyone). The implications of the extended model can be illustrated with three examples.

\section{Example 1: Higher average income leads to lower corruption.}

The first example is almost trivial and involves no heterogeneity at all. Let $\theta(j)=\theta$, and $z(j)=x$. In other words, everyone is the same as everyone else. Since the median voter is the same as the average voter, her choice trivially also maximizes the social welfare. The only difference between this example and the benchmark model is that the effect of corruption now depends on the level of income, which is an additional assumption.

By item (ii) in Proposition 2, we have $\mathrm{dt}(\mathrm{j}) / \mathrm{dx}>0$. Thus, as the average income level rises, the desired level of resources for public institutions also rises, leading to a lower level of corruption. This example is a near tautology, but serves as a stepping stone to the next example. 


\section{Example 2: Income Inequality}

In this example, people are different only in terms of their level of income. Suppose further that $z(j)=x(j)[$ and $\theta(j)=\theta$, the same for all $j$ 's. .

Income distribution can take many different forms. In principle, median income can be either greater or smaller than average income. However, a typical case of income inequality is one in which median income is below the average (e.g., a few rich people plus a mass of poor people). In this case we can use the difference between average and median incomes as a way to measure income inequality.

Holding average income constant, the greater the inequality, the lower is the median income. By Proposition 2, item (ii), the median voter will prefer a lower level of resources going into public institution building than will the average voter. By the median voter theorem, the median voter's preference decides the public policy. Hence, a rise in income inequality leads to a rise in the corruption level.

\section{Example 3: Ethnic Fragmentation}

This example is chosen because ethnic fragmentation has been a popular instrumental variable for corruption in regressions that examine the effects of corruption ${ }^{\text {B }}$. In our example, we show that there are no clear-cut predictions with regard to the effect of ethnic fragmentation.

In this example, people are different only in terms of their ethnic identity. For simplicity, let $\mathrm{z}(\mathrm{j})=1$ for all $\mathrm{j}$. $\theta(\mathrm{j})$ differs with $\mathrm{j}$ 's ethnic group membership. We can use the gap between $\theta$ (median) and $\theta$ (average) to measure the extent of ethnic fragmentation.

Case 1: There is a dominant ethnic group in the sense that the median (pivotal) voter belongs to this group. The dominant group engages in international trade/business more than other ethnic groups. In this case, $\theta$ (median) $>\theta$ (average). According to Proposition 2 , item (iii), the median voter prefers a higher level of public governance than the mean voter. Hence, holding $\theta$ (average) constant, a greater divergence in preference along the ethnic line [or greater $\theta$ (median)- $\theta$ (average)] can lead to more resources devoted to public institutional building, and hence lower corruption.

Case 2: If the median voter is still in the dominant ethnic group. But the dominant group engages in less international trade than other groups. That is, $\theta$ (median) $<\theta$ (average). In this 
case, holding $\theta$ (average) constant, a greater divergence in preference along the ethnic line [or greater $\theta($ average $)-\theta($ median $)]$ would lead to less resources devoted to public institutional building, and hence more corruption.

These two cases are not exhaustive of all possibilities. Hence, it is important to note that this example does not prove any solid prediction, but merely illustrates the possibility of a nonmonotonic relationship between ethnic fragmentation and corruption.

\section{Empirics}

We now turn to empirical evidence on the connection between quality of government and natural openness. We look at two different dimensions of the quality of government: (a) a measure of an output of public governance, namely the level of bureaucratic corruption; and (b) a measure of an input into public governance, namely civil servant salaries relative to their private sector alternative.

We proceed in the following way. We first explain how "natural openness" is defined and constructed, but we leave a complete explanation of the source and definition of the other variables to a separate data appendix. We then investigate via a sequence of regressions. We will examine data from two separate periods: late 1970s/early 1980s and mid-1990s.

\section{Measuring Natural Openness}

We decompose the conventional measure of openness - exports plus imports, as percentage of GDP - into "natural openness" and "residual openness" by estimating what level of openness a country should have based on its size, geographic and linguistic characteristics. Specifically, we run the following regression:

$$
\begin{aligned}
& \log \left[\frac{\exp \operatorname{ort}(k)+\operatorname{import}(k)}{G D P(k)}\right]=\beta_{1} \operatorname{Re} \text { moteness }(k)+\beta_{2} \log [\operatorname{population}(k)] \\
& + \text { language_dummies }+ \text { geographic_dummies }+e(k)
\end{aligned}
$$

\footnotetext{
3 See Mauro (1995) and Treisman (1998), for example.
} 
We define the fitted value from such a regression as a measure of the country's 'natural openness,' and label the residual as "residual openness.'

Such a regression resembles the empirically highly successful gravity equation in the trade literature except that its dependent variable is a country's trade-to-GDP ratio rather than bilateral trade. One can find a long list of empirical papers using the gravity equation. Recent applications include Frankel, Stein and Wei (1995) and Rose (1999). Frankel and Romer (1999) applied the gravity equation to construct an instrumented variable for openness, which is related to our "natural openness" measure. The theoretical foundation of the gravity equation has been provided by Helpman and Krugman (1985), and Deardorff (1998), among others.

We construct "Remoteness" to capture how far a country is from the rest of the world. Intuitively, Argentina, being at the tip of South America, is farther away from the world market than is France, a country in the heart of the European continent. If other things were equal, France would naturally have a higher trade-to-GDP ratio than Argentina. An empirical measure of "remoteness" was first constructed by Wei (1996). Here, we construct country k's remoteness as a weighted-average of its distance to all other countries in the world. We use each country's share of total trade in the world's total trade as the weights ${ }^{\natural}$.

$$
\operatorname{Re} \operatorname{motenss}(k)=\sum_{j \neq k} w(j) \log [\operatorname{Dis} \tan c e(k, j)]
$$

where $w(j)=\frac{\operatorname{trade}(j)}{\sum_{i \neq j} \operatorname{trade}(i)}$

and trade(j) is country j's exports plus imports, averaged over three years.

For language abilities, we construct three dummies, "English," "French," and "Spanish," each of which takes the value of one if the country speaks the respective language, and zero otherwise. For other geographic characteristics, we construct a dummy, "landlock" if the country is landlocked; another dummy, "island" if the country is an island, and finally, the ratio of the length a country's sea coast to its land area, labeled as "coast-to-land area ratio."

We first explain the construction of "natural openness" in the late 1970s/early 1980s. Table 2 a reports a succession of regressions on openness (exports plus imports divided by GDP, 
averaged over 1978-80. In column 1, only remoteness and $\log$ (population) are included. The coefficient estimates are both negative and statistically significant: countries that are more distant from the world market are less open; and large countries are less open. These patterns match up with the assumption on "natural openness," $\mathrm{P}(\mathrm{k} \in \mathrm{W})$ or $\mathrm{f}($.$) , in the model in Section 2$.

In Columns 2-4, we successively add the "landlock" dummy, the ratio of coastal length to land area, and the "island" dummy. When the "landlock" dummy is added by itself, its coefficient estimate is negative, consistent with the notion that landlocked countries trade less. The positive sign on the other two coefficients are consistent with the notions that a country with a longer coast is more open, and that an island economy is more open than otherwise. However, none of the coefficients on the three variables are statistically significantly from zero. So we cannot draw definitive conclusions here.

In Column 5, we add three dummies for the three major international languages, English, French and Spanish. The English dummy is positive and significant at the five percent level: English language ability facilitates international trade. The French and the Spanish dummies are not statistically significant. In Column 6, we report a regression that only includes the three regressors that are significant at the ten percent level or better (Remoteness, log Population, and English) in the previous columns.

In the subsequent empirical tests, we will use Column 5 in this table as the benchmark. We will define the fitted values from this regression as a measure of "natural openness" and label the residuals as "residual openness." As a robustness check, we construct measures of "natural openness" and "residual openness" based on the more parsimonious regression in Column 6. The results are sufficiently close that we will report only the first set of results.

For openness ( $\log ($ total trade/GDP)) averaged over 1994-96, we perform a similar set of regressions. The results are reported in Table $2 \mathrm{~b}$. Because these results are sufficiently similar to those in Tables 2a, we omit discussing them to save space. In subsequent tests on openness and corruption in the late 1990s, we construct "natural openness" as the fitted values from the equation in Column 5 of Table $2 \mathrm{~b}$, and "residual openness" as the residuals from the same column. As a robustness check, we will also construct the same pair of natural and residual openness measures based on Column 6 of Table $2 b$.

\footnotetext{
${ }^{4}$ For this measure, the "world" consists of 169 countries in our 1978-80 sample, and 184 countries in our 1994-96 sample. The distance measure for a particular pair of countries is the "greater circle distance" between the economic centers of the two countries, typically the capitals. For details, please see the data appendix.
} 
Natural Openness and Corruption

We now turn to an examination of the relationship between natural openness and (perceived level of) corruption across countries. We make use of two different measures of corruption from two separate periods: the Business International (BI) corruption index, averaged over 1980-83, the Transparency International (TI) corruption index in 1998. The first index is based on Business International's in-house survey of experts. It is the earliest perception-based measure available and was first used by Paolo Mauro (1995). The second index is an average of many other indexes of corruption in the $1990 \mathrm{~s}^{\mathrm{B}}$. Neither index is perfect. So we hope that the evidence from the two are complimentary to each other.

We start with evidence from the early 1980s where corruption measure is the BI-index, averaged over 1980-83. Table 3 reports the basic regressions. In Column 1, when natural openness is entered by itself, its coefficient is negative and significant at the five percent level: naturally more open economies exhibit less corruption, exactly as our theoretical discussion has predicted. In Column 2, we add "residual openness," or the deviation of actual openness from the natural level. One possible reason for this deviation is government trade policies, which can cause the country to engage in more or less trade than its natural openness would have suggested. Somewhat surprisingly, the coefficient on the "residual openness" is not different from zero. In other words, the correlation between openness and corruption does not appear to go beyond what can be explained by geography, size and language abilities. Trade policies, in particular, appear to have played a relatively small role if at all in explaining corruption ${ }^{6}$.

In accordance with our theoretical discussion, richer countries tend to build better public institutions and display less corruption (and, outside our model, the reverse causality is also possible). In Column 3, we include per capital GDP as an additional control variable. Not surprisingly, the coefficient on this variable is negative and significant, confirming the notion that rich countries tend to have less corruption. Once per capital GDP is controlled for, the

\footnotetext{
${ }^{5}$ The TI index is an avearge of indexes from Political \& Economic Risk Consultancy's Asian Intelligence Issue, Gallup International $50^{\text {th }}$ Anniversary Survey (1997), Freedom House, Institute for Management Development's World Competitiveness Yearbooks, World Economic Forum's Global Competitiveness Report, Political Risk Services, World Bank's World Development Report 1997 survey, and Economist Intelligence Unit's Country Risk Service and Country Forecast.
} 
coefficient on natural openness drops substantially in absolute value (from -2.6 to -1.3 ).

However it remains negative and significant. In other words, naturally more open economies have less corruption, and this relationship goes beyond the fact rich countries are both more open and less corrupt.

One remedy for corruption is democratic institutions. Democracy offers a mechanism to monitor the behavior of government officials more closely. One would expect that democracy helps to deter corruption. To check this, we include a measure of democracy as another control variable in Column 4. Unfortunately, democracy is not statistically different from zero (though it does have a negative coefficient). In Column 5, we add democracy by itself. Its coefficient is negative and significant: more democratic countries tend to have less corruption. However, the significance of the coefficient on democracy does not survive the addition of per capital GDP as a regressor. Hence, the democracy-corruption association merely reflects the fact that many rich countries are democracies and at the same time have less corruption.

In Table 4, we consider a few more regressors that other authors have found to be important. First, we include "ethno-linguistic fractionalization," which measures the probability that two random persons from a country are not from the same ethnic group, and was first introduced into the economics literature by Mauro (1995). Somewhat surprisingly, this measure is not statistically significant in our regressions.

[Some further probing indicates that if the ethno-linguistic fractionalization variable enters the regression by itself, it is positive and significant, exactly as in Mauro (1995). However, adding per capital GDP to the regression results in a loss of statistical significance and a switch in the coefficient's sign.]

Treisman (1998) argued that federal states produce more corruption than unitary states. We include his dummy variable for federal states in Column 3. Contrary to his findings, we find that federal states have a coefficient point estimate that is essentially zero. On the other hand, Fisman and Gatti (1999) used different measures of fiscal decentralization and found that more decentralized economies tend to have lower corruption. Their two measures of decentralization are either the share of the provincial and local governments in total government expenditure, or the share of the provincial and local governments in total government revenues. In the last two

\footnotetext{
${ }^{6}$ More precisely, trade policies that attempt to pull a country away from its "natural openness" do not appear to
} play a big role in explaining cross-country differences in corruption. 
columns of Table 4, we include the two Fisman-Gatti measures of fiscal decentralization. We confirm their finding that more decentralized economies do tend to have lower level of corruption as well. Here we do not want to get into the issue of direction of causality between federalism and corruption. Instead, we wish to emphasize that controlling for the degree of decentralization, the coefficient on "natural openness" continues to be negative and significant.

As a robustness check, we also use an alternative measure of corruption generated by a different organization (Transparency International, or TI) at a different time period (1998). The TI also employed a different methodology from BI: As explained before, it pools together surveys from a large number of sources. Using the TI corruption ratings, we replicate the key regressions in the earlier tables (with the regressors lagged by an appropriate period). The results are reported in Tables 5-6. Broadly speaking, the results are qualitatively the same as before. First, the natural openness is always associated with less corruption. Second, residual openness is found to be insignificant throughout the tables. Third, high per capital GDP is associated with less corruption. Four, "democracy" does show up with a negative coefficient, consistent with the conventional wisdom. Fiscal decentralization as measured either by expenditure share or the revenue share of the local government in total governments' finance is also associated with less corruption.

\section{Natural Openness and Public Sector Pay}

Bureaucratic corruption can be viewed as an indicator of government performance. So the previous discussions centered on the connection between natural openness and the outcome of the public institutions. Here, we ask how natural openness may affect an intermediate building block of public institutions, namely the salaries of the government officials relative to their private sector alternatives.

Piecing together information from several sources including the IMF's (internal) Recent Economic Development (RED), national statistical sources, the IMF's Government Fiscal Statistics, the International Labor Organizations' annual statistical books, and occasionally World Bank memos, Van Rijckeghem and Weder (1999) constructed a measure of civil servant salaries relative to their manufacturing sector wages. Manufacturing wages may not be a correct measure of the bureaucrat's private sector alternative. However, under the assumption that the bureaucrat's true private sector alternative is a constant multiplier of the manufacturing wage 
across countries (plus a random error), then their measure would be exactly right in terms of getting the appropriate cross-country variation in a regression. In any case, van Rijckeghem and Weder reported fairly clear evidence that low public sector wages tend to be associated with high bureaucratic corruption ${ }^{\mathrm{B}}$.

Because the public sector's relative salary is an input into the building of public governance rather than an output (such as corruption), it offers a good and separate channel to check our model's predictions regarding natural openness and quality of government. Table 7 reports the regression results on this question. In Column 1, we include "natural openness" as the only regressor. It has a positive and significant coefficient: a 10\% increase in "natural openness" is associated with a $4 \%$ increase in the public sector salary relative to their private sector alternative. In Column 2, we add "residual openness." Both natural and residual openness have positive and significant coefficients. This suggests that, in addition to natural openness, other factors that promote openness, such as deliberate government policies, are also positively associated with the decision to pay civil servants better salaries. In Column 3, per capita GDP is added to the regression which has a positive coefficient: higher income countries on average choose to pay civil servants better. Controlling for the per capita income effect, both natural openness and residual openness continue to have a positive and significant effect on the public sector's relative salaries.

\section{Conclusion}

This paper offers a new interpretation of the connection between openness and quality of government. Countries are different in terms of their natural propensity to be open to international trade/business. Because foregone trade and business opportunities due to corruption and bad governance would be greater for naturally more open economies, they would choose to invest more in building good public governance and would display less corruption. An extension of our model suggests that the incentive to invest in good public governance also

\footnotetext{
${ }^{7}$ Rauch and Evans (2000) constructed their own index of public sector relative salaries based on an average of the answers to two survey questions by developing countries officials, one on the level of public salaries, and the other on the growth rate of the salaries. They failed to find a statistically significant relationship between their measure of relative public sector wage and corruption. However, decomposing the Rauch-Evans index back to their components (wage level and wage growth), Van Rijckeghem and Weder (1999, Column 3 in their Table 1) found that there is still a negative and significant relationship between corruption and the level of public sector wage.
} 
increases with the average income level, and decreases with income equality. The effect of ethnic fragmentation is likely to be complex rather than simple.

The predictions of the model are examined with data from the early 1980s and from the late 1990s. Both an outcome indicator of public governance (the level of bureaucratic corruption) and an input indicator (public sector relative wage) are related to natural openness.

Consistent patterns are found in the data. First, a naturally more open economy tends to display a lower level of corruption. This is true even after controlling for the level of development and other possible determinants of corruption. Second, residual openness - which potentially includes the effect of trade policies - is not found to be important in explaining corruption once natural openness is accounted for. Third, a naturally more open economy also tends to pay better salaries to its civil servants, which is indicative of the marginal benefit of better governance in a society's revealed preference.

Finally, one can say a few words about globalization and corruption. A country's "natural openness" rises when other countries liberalize their trade and investment, or when the costs of international trade and business decline due to technological reasons. Both global trade/investment liberalization and technological advancement are ingredients of globalization. Therefore, globalization potentially can raise every country's "natural openness." In the logic of this paper, this can enhance every country' incentive to build good governance and to reduce corruption. In short, globalization can reduce corruption. 


\section{References}

Ades, Alberto, and Rafael Di Tella, "Rents, Competition, and Corruption," Economic Review, September, 89(4): 982-993.

Deardorff, Alan, 1998, “A Theoretical Foundation for Gravity Model,” Jeffrey Frankel, ed., The Regionalization of the World Economy, Chicago: University of Chicago Press.

Frankel, Jeffrey, and David Romer, 1999, “Trade and Growth,” American Economic Review.

Frankel, Jeffrey, Ernesto Stein, and Shang-Jin Wei, 1995, "Trading Blocs and the Americas: Natural, Unnatural, and Supernatural?” Journal of Development Economics June, 47: 61-95.

Fisman, Raymond, and Roberta Gatti, 1999, "Decentralization and Corruption: Evidence Across Countries," Columbia Business School and the World Bank.

Gatti, Roberta, 1999, “Explaining Corruption: Are Open Countries Less Corrupt?” working paper, The World Bank.

Helpman, Elhanan and Paul Krugman, 1985, Market Structure and Foreign Trade, Cambridge, MA: MIT Press.

La Porta, Rafael, Florencio Lopez-de-Silanes, Andrei Shleifer, and Robert Vishny, 1998, "The Quality of Government," Journal of Law, Economics and Organization, Vol. 15, p681712.

Mauro, Paolo, 1995, “Corruption and Growth,” Quarterly Journal of Economics, August, 110: $681-712$.

Kaufmann, Daniel and Shang-Jin Wei, 1999, “Does 'Grease Money' Speed Up the Wheels of Commerce?" NBER Working Paper 7093, April.

Rauch, James and Peter Evans, 2000, "Bureaucratic Structure and Economic Performance in Less Developed Countries," Journal of Public Economics, 75(1): 49-71.

Rose, Andrew, 1999, 'One Money, One Market: Estimating the Effect of Common Currencies on Trade," NBER Working Paper 7432, December.

Tamirisa, Natalia, and Shang-Jin Wei, 2000, "Bribery in Trade: Liberalizing Grease or Non-tariff Barrier?" IMF and Harvard University. 
Treisman, 1998, "The Causes of Corruption: A Cross-national Study," Department of Political Science, University of California-Los Angels.

Van Rijckeghem, Caroline and Beatrice Weder, 1997, "Corruption and the Rate of Temptation: Do Low Wages in the Civil Service Cause Corruption?" IMF Working Paper, WP/97/73.

Wei, Shang-Jin, 1996, "Intra-National versus International Trade: How Stubborn are Nations in Global Integration?' NBER Working Paper 5531, April. Downloadable at http://papers.nber.org/papers/W5531.

Wei, Shang-Jin, 2000, "How Taxing is Corruption on International Investors?" Review of Economics and Statistics, February, 82(1): 1-11. 


\section{Data Appendix to "Natural Openness and Good Government"}

\section{Corruption - Business International (BI)}

Source: Paolo Mauro, 1995 Quarterly Journal Economics, "Corruption and growth".

Rankings are the average for 1980-83. We transform the data by the following method: Our ratings $=10$-original ratings. Thus, larger numbers mean more corrupt governments.

\section{Corruption -Transparency International (TI)}

Source: Transparency International 1998 index (http://www.gwdg.de/ uwvw/icr.htm),

Our ratings $=10$-original ratings. Thus, larger numbers mean more corrupt governments.

\section{Per capita GDP}

Log GDP per capita averaged over 1978-80

$=[\log ($ GDP78/Population78) $+\log ($ GDP79/Population79 $)+\log ($ GDP80/Population80 $)] / 3$

GDP in 1995 constant dollars using Chain index (1985 international prices in PWT5)

Source: Penn World Table 5.6 (http://datacentre.chass.utoronto.ca/pwt)

Log GDP per capita averaged over 1994-96

GDP are in constant 1995 US\$.

Source: World Development Indicator, the World Bank

Openness $78-\mathbf{8 0}=\log$ (total trade and services / GDP) averaged over 1978-80

Openness 94-96 = Log (total trade and services / GDP) averaged over 1994-96

Source: World Bank's GDF/WDI Database.

\section{Length of Coast}

Source: World Resources Institute, World Resources 1996-97 database diskette.

\section{Land Area}

Source: World Bank’s GDF/WDI Database

\section{Ethno-linguistic fractionalization}

Source: Eaterly, William and Ross Levine, 1996, “Africa's Growth Tragedy: Policies and Ethnic Divisions", downloaded from www.worldbank.org/html/prdmg/grthweb/ftpdata.htm.

Democracy in 1983/93

Source: Freedom House

Eight minus the sum of civil rights and political rights in 1983 and 1993 . Converted so a higher figure indicates higher democracy.

\section{Gini Coefficient for Income Distribtution}

Source: Deininger, Klaus and Lyn Squire, 1996, "A New Data Set Measuring Income Inequality," Wold Bank Econmic Review 10 (3): 565-591.

GINI is the abbreviation for Gini index. Gini index measures the extent to which the distribution of income (or, in some cases, consumption expenditures) among individuals or households within an economy deviates from a perfectly equal distribution. A Lorenz curve plots the 
cumulative percentages of total income received against the cumulative number of recipients, starting with the poorest individual or household. The Gini index measures the area between the Lorenz curve and a hypothetical line of absolute equality, expressed as a percentage of the maximum area under the line. Thus a Gini index of zero represents perfect equality while an index of 100 implies perfect inequality.

Source: same as GINI

The income difference of top $20 \%$ and bottom $20 \%$.

DISTRIB is the abbreviation for income share of bottom $40 \%$. Percentage share of income or consumption is the share that accrues to subgroups of population indicated by quintiles.

Percentage shares by quintiles may not add up to 100 because of rounding.

\section{Federalism}

A dummy that equals to one if country is a federal state and zero otherwise.

Source: Treisman (1998)/

\section{Fiscal Decentralization}

Share of state or lower governments in the total government expenditure or revenue. Source: Fisman and Gatti (1999). Courtesy of Roberta Gatti.

Government Wage / Manufacturing Sector Wage

Source: Van Ricjkhem and Weder (1997). Courtesy of Caroline Van Rickeghem. 
Table 1a: summary statistics

\begin{tabular}{lrcccc}
\hline Variable & Obs. & Mean & Std. Dev. & Min & Max \\
\hline Corruption-BI & 67 & 3.31 & 2.58 & 0 & 9 \\
Corruption-TI & 83 & 5.22 & 2.34 & 0 & 8.6 \\
Ln (trade/GDP): 78-80 & 140 & 4.17 & 0.64 & 2.44 & 5.99 \\
Ln (trade/GDP): 94-96 & 162 & 4.28 & 0.58 & 1.11 & 5.87 \\
Ln(GDP/POP): 78-80 & 133 & 7.88 & 1.05 & 5.76 & 10.43 \\
Ln(GDP/POP): 94-96 & 158 & 7.42 & 1.56 & 4.64 & 10.68 \\
Public sector relative wage (91) & 30 & 1.08 & 0.50 & 0.22 & 2.24 \\
\hline
\end{tabular}

Note:

1. GDP per capital for 94-96 are at constant 1995 US\$ from GDF/WDI (The World Bank). GDP per capita for 7880 are for constant dollars using Chain index (1985 international price) from Penn World Table 5.6.

2. Corruption indexes: $1978-80$ for BI and 1998 for TI.

Table 1b: Pairwise Correlation

\begin{tabular}{lcccccc}
\hline & BI & TI & openness & openness & income & Income \\
\hline TI & & & $78-80$ & $94-96$ & $78-80$ & $94-96$ \\
Ln (trade/GDP): 78-80 & 0.79 & 1 & & & & \\
Ln (trade/GDP): 94-96 & -0.24 & -0.31 & 1 & & & \\
Ln(GDP/POP): 78-80 & -0.18 & -0.19 & 0.82 & 1 & & \\
Ln(GDP/POP): 94-96 & -0.66 & -0.77 & 0.25 & 0.24 & 1 & \\
Public sector relative wage & -0.69 & -0.82 & 0.19 & 0.11 & 0.94 & 1 \\
\hline
\end{tabular}




\section{Table 2a: Explaining Openness}

(averaged over 1978-80)

\begin{tabular}{|c|c|c|c|c|c|c|}
\hline \multicolumn{7}{|l|}{ Dependent Variable: Log Openness } \\
\hline & 1 & 2 & 3 & 4 & 5 & 6 \\
\hline Remoteness & $\begin{array}{c}-0.272 * * \\
(0.080)\end{array}$ & $\begin{array}{l}-0.269 * * \\
(0.081)\end{array}$ & $\begin{array}{c}-0.277 * * \\
(0.080)\end{array}$ & $\begin{array}{c}-0.299 * * \\
(0.082)\end{array}$ & $\begin{array}{l}-0.329 * * \\
(0.093)\end{array}$ & $\begin{array}{c}-0.316^{* *} \\
(0.077)\end{array}$ \\
\hline Log population & $\begin{array}{l}-0.258 * * \\
(0.021)\end{array}$ & $\begin{array}{l}-0.260 * * \\
(0.021)\end{array}$ & $\begin{array}{c}-0.241 * * \\
(0.024)\end{array}$ & $\begin{array}{c}-0.238 * * \\
(0.024)\end{array}$ & $\begin{array}{l}-0.235^{* *} \\
(0.024)\end{array}$ & $\begin{array}{c}-0.252 * * \\
(0.021)\end{array}$ \\
\hline Landlock dummy & & $\begin{array}{l}-0.161 * \\
(0.095)\end{array}$ & $\begin{array}{l}-0.115 \\
(0.095)\end{array}$ & $\begin{array}{l}-0.094 \\
(0.096)\end{array}$ & $\begin{array}{l}-0.099 \\
(0.100)\end{array}$ & \\
\hline Coast length divided by land area & & & $\begin{array}{l}0.884 \# \\
(0.547)\end{array}$ & $\begin{array}{c}0.629 \\
(0.627)\end{array}$ & $\begin{array}{c}0.561 \\
(0.580)\end{array}$ & \\
\hline island dummy & & & & $\begin{array}{c}0.133 \\
(0.116)\end{array}$ & $\begin{array}{c}0.107 \\
(0.122)\end{array}$ & \\
\hline English dummy & & & & & $\begin{array}{l}0.174 * \\
(0.091)\end{array}$ & $\begin{array}{l}0.213 * * \\
(0.080)\end{array}$ \\
\hline French dummy & & & & & $\begin{array}{l}-0.002 \\
(0.091)\end{array}$ & \\
\hline Spanish dummy & & & & & $\begin{array}{l}-0.014 \\
(0.101)\end{array}$ & \\
\hline $\mathrm{R} 2$ & 0.54 & 0.55 & 0.57 & 0.57 & 0.59 & 0.57 \\
\hline No. of Obs. & 126 & 126 & 125 & 125 & 125 & 126 \\
\hline \multicolumn{7}{|c|}{$\begin{array}{l}\text { Note: } \\
1 . * *, * \text { and } \# \text { denote significant at the } 55,10 \% \text {, and } 15 \% \text { level, respectively. Robust standard errors are in } \\
\text { parentheses. }\end{array}$} \\
\hline 2. remoteness for country $\mathrm{k} \equiv \sum_{j}$ & Distance $\left._{\mathrm{jk}}\right)$. & & & & & \\
\hline
\end{tabular}


Table 2b: Explaining Openness

(averaged over 1994-96)

\begin{tabular}{|c|c|c|c|c|c|c|}
\hline \multicolumn{7}{|c|}{ Dependent Variable: Log Openness } \\
\hline & 1 & 2 & 3 & 4 & 5 & 6 \\
\hline Remoteness & $\begin{array}{c}-0.275^{* *} \\
(0.075)\end{array}$ & $\begin{array}{c}-0.276^{* *} \\
(0.076)\end{array}$ & $\begin{array}{c}-0.272 * * \\
(0.077)\end{array}$ & $\begin{array}{c}-0.299 * * \\
(0.080)\end{array}$ & $\begin{array}{c}-0.370 * * \\
(0.112)\end{array}$ & $\begin{array}{c}-0.345^{* *} \\
(0.081)\end{array}$ \\
\hline Log population & $\begin{array}{c}-0.201 * * \\
(0.023)\end{array}$ & $\begin{array}{c}-0.202 * * \\
(0.023)\end{array}$ & $\begin{array}{c}-0.195^{* *} \\
(0.025)\end{array}$ & $\begin{array}{c}-0.188^{* *} \\
(0.025)\end{array}$ & $\begin{array}{c}-0.190^{* *} \\
(0.025)\end{array}$ & $\begin{array}{c}-0.198^{* *} \\
(0.023)\end{array}$ \\
\hline Landlock dummy & & $\begin{array}{l}-0.030 \\
(0.077)\end{array}$ & $\begin{array}{l}-0.015 \\
(0.078)\end{array}$ & $\begin{array}{c}0.013 \\
(0.078)\end{array}$ & $\begin{array}{c}0.025 \\
(0.078)\end{array}$ & \\
\hline $\begin{array}{l}\text { Coast length divided } \\
\text { by land area }\end{array}$ & & & $\begin{array}{c}0.242 \\
(0.316)\end{array}$ & $\begin{array}{c}0.196 \\
(0.259)\end{array}$ & $\begin{array}{c}0.171 \\
(0.234)\end{array}$ & \\
\hline Island dummy & & & & $\begin{array}{c}0.158 \\
(0.118)\end{array}$ & $\begin{array}{c}0.111 \\
(0.117)\end{array}$ & \\
\hline English dummy & & & & & $\begin{array}{l}0.173^{*} \\
(0.098)\end{array}$ & $\begin{array}{c}0.198^{* *} \\
(0.086)\end{array}$ \\
\hline French dummy & & & & & $\begin{array}{c}-0.134 \# \\
(0.089)\end{array}$ & \\
\hline Spanish dummy & & & & & $\begin{array}{c}0.068 \\
(0.128)\end{array}$ & \\
\hline $\mathrm{R} 2$ & 0.36 & 0.36 & 0.37 & 0.37 & 0.40 & 0.38 \\
\hline No. of Obs. & 153 & 153 & 152 & 152 & 152 & 153 \\
\hline
\end{tabular}

Note: remoteness for country $\mathrm{k} \equiv \sum_{j} \mathrm{~W}_{\mathrm{jt}} \log \left(\right.$ Distance $\left._{\mathrm{jk}}\right)$.

$\mathrm{W}_{\mathrm{kt}} \equiv($ total trade by country $\mathrm{k}$ in year $\mathrm{t}) / \sum_{i \neq j}$ total trade $\mathrm{i}_{\mathrm{i}}$. Total trade is the average over 1994-96. 


\section{Table 3: Natural Openness \& Corruption \\ $($ Corruption $=\mathrm{BI}$ index, averaged over 1980-83)}

\begin{tabular}{|c|c|c|c|c|c|}
\hline Dependent variable: $\mathrm{BI}$ corruption & & & & & \\
\hline & 1 & 2 & 3 & 4 & 5 \\
\hline Natural openness & $\begin{array}{c}-2.454^{* *} \\
(0.774)\end{array}$ & $\begin{array}{c}-2.613^{* *} \\
(0.795)\end{array}$ & $\begin{array}{l}-1.300^{*} \\
(0.661)\end{array}$ & $\begin{array}{c}-1.284^{*} \\
(0.684)\end{array}$ & $\begin{array}{c}-1.945^{* *} \\
(0.757)\end{array}$ \\
\hline Residual openness & & $\begin{array}{c}0.359 \\
(0.645)\end{array}$ & $\begin{array}{c}0.428 \\
(0.489)\end{array}$ & $\begin{array}{c}0.008 \\
(0.455)\end{array}$ & $\begin{array}{l}-0.327 \\
(0.581)\end{array}$ \\
\hline Log per capital GDP & & & $\begin{array}{c}-1.817^{* *} \\
(0.268)\end{array}$ & $\begin{array}{c}-1.469^{* *} \\
(0.416)\end{array}$ & \\
\hline Democracy & & & & $\begin{array}{c}-0.127 \\
(0.096)\end{array}$ & $\begin{array}{c}-0.364 * * \\
(0.066)\end{array}$ \\
\hline R2 & 0.14 & 0.15 & 0.54 & 0.57 & 0.43 \\
\hline No. of Obs. & 66 & 65 & 65 & 63 & 63 \\
\hline
\end{tabular}

Note:

1. natural openness is the predicted value of column 5 in table $2 \mathrm{a}$.

2. residual openness is the residual from column 5 in table 2 a.

3. Democracy is the sum of civil liberties index and political right index in 1983 (re-scaled so that a higher value indicates more democratic). 


\section{Table 4: Controlling Additional Determinants Of Corruption}

$($ Corruption $=$ BI index, averaged over 1980-83)

\begin{tabular}{|c|c|c|c|c|c|}
\hline \multicolumn{6}{|l|}{ Dependent variable: BI corruption } \\
\hline & 1 & 2 & 3 & 4 & 5 \\
\hline Natural openness & $\begin{array}{l}-1.375^{*} \\
(0.703)\end{array}$ & $\begin{array}{l}-1.411^{*} \\
(0.807)\end{array}$ & $\begin{array}{r}-1.087 \# \\
(0.715)\end{array}$ & $\begin{array}{l}-2.176^{*} \\
(1.115)\end{array}$ & $\begin{array}{l}-1.977^{*} \\
(1.073)\end{array}$ \\
\hline Residual openness & $\begin{array}{c}0.449 \\
(0.510)\end{array}$ & $\begin{array}{c}0.428 \\
(0.996)\end{array}$ & $\begin{array}{l}-0.472 \\
(0.481)\end{array}$ & $\begin{array}{l}-0.507 \\
(0.700)\end{array}$ & $\begin{array}{l}-0.599 \\
(0.723)\end{array}$ \\
\hline Log per capital GDP & $\begin{array}{c}-1.884 * * \\
(0.303)\end{array}$ & $\begin{array}{c}-1.887 * * \\
(0.317)\end{array}$ & $\begin{array}{c}-1.042^{* *} \\
(0.302)\end{array}$ & $\begin{array}{l}-0.153 \\
(0.559)\end{array}$ & $\begin{array}{l}-0.163 \\
(0.576)\end{array}$ \\
\hline Ethno-linguistic fractionalization & $\begin{array}{l}-0.004 \\
(0.009)\end{array}$ & $\begin{array}{l}-0.009 \\
(0.084)\end{array}$ & & & \\
\hline $\begin{array}{l}\text { Ethno-linguistic fractionalization } \\
* \text { natural openness }\end{array}$ & & $\begin{array}{c}0.001 \\
(0.022)\end{array}$ & & & \\
\hline $\begin{array}{l}\text { Ethno-linguistic fractionalization } \\
* \text { residual openness }\end{array}$ & & $\begin{array}{c}0.001 \\
(0.020)\end{array}$ & & & \\
\hline Democracy & & & $\begin{array}{c}-0.284^{* *} \\
(0.068)\end{array}$ & $\begin{array}{l}-0.240 \\
(0.171)\end{array}$ & $\begin{array}{l}-0.278 \# \\
(0.166)\end{array}$ \\
\hline Federalism & & & $\begin{array}{c}0.111 \\
(0.426)\end{array}$ & & \\
\hline Decentralization (expenditure) & & & & $\begin{array}{c}-5.617 * * \\
(1.921)\end{array}$ & \\
\hline Decentralization (revenue) & & & & & $\begin{array}{c}-5.520 * * \\
(1.993)\end{array}$ \\
\hline R2 & 0.53 & 0.53 & 0.63 & 0.59 & 0.57 \\
\hline No. of Obs. & 64 & 64 & 63 & 39 & 39 \\
\hline
\end{tabular}


Table 5: Natural Openness \& Corruption

$($ Corruption $=$ TI index, 1998$)$

\begin{tabular}{|c|c|c|c|c|c|}
\hline Dependent variable: TI corruption & & & & & \\
\hline & 1 & 2 & 3 & 4 & 5 \\
\hline Natural openness & $\begin{array}{c}-3.176^{* *} \\
(0.648)\end{array}$ & $\begin{array}{c}-3.227 * * \\
(0.631)\end{array}$ & $\begin{array}{c}-1.536 * * \\
(0.456)\end{array}$ & $\begin{array}{c}-1.595^{* *} \\
(0.513)\end{array}$ & $\begin{array}{c}-1.155 \# \\
(0.696)\end{array}$ \\
\hline Residual openness & & $\begin{array}{c}0.753 \\
(0.599)\end{array}$ & $\begin{array}{l}-0.046 \\
(0.342)\end{array}$ & $\begin{array}{c}-0.057 \\
(0.413)\end{array}$ & $\begin{array}{l}-0.317 \\
(0.642)\end{array}$ \\
\hline Log per capital GDP & & & $\begin{array}{c}-1.177^{* *} \\
(0.111)\end{array}$ & $\begin{array}{c}-1.247^{* *} \\
(0.140)\end{array}$ & \\
\hline Democracy & & & & $\begin{array}{c}0.036 \\
(0.071)\end{array}$ & $\begin{array}{c}-0.444 * * \\
(0.066)\end{array}$ \\
\hline R2 & 0.20 & 0.22 & 0.71 & 0.71 & 0.47 \\
\hline No. of Obs. & 82 & 82 & 82 & 80 & 80 \\
\hline
\end{tabular}

1. natural openness is the predicted value of openness regressing on all the explanatory variables in table $2 \mathrm{~b}$ (second to the last column). 


\section{Table 6: Controlling Additional Determinants of Corruption}

$($ Corruption $=$ TI index, 1998)

\begin{tabular}{|c|c|c|c|c|c|}
\hline Dependent variable: Ti corruption & & & & & \\
\hline & 1 & 2 & 3 & 4 & 5 \\
\hline Natural openness & $\begin{array}{c}-1.987 * * \\
(0.540)\end{array}$ & $\begin{array}{l}-2.263 * * \\
(0.773)\end{array}$ & $\begin{array}{l}-1.623 * * \\
(0.584)\end{array}$ & $\begin{array}{c}-1.836^{* *} \\
(0.628)\end{array}$ & $\begin{array}{c}-1.711^{* *} \\
(0.613)\end{array}$ \\
\hline Residual openness & $\begin{array}{l}-0.062 \\
(0.352)\end{array}$ & $\begin{array}{l}-0.343 \\
(0.586)\end{array}$ & $\begin{array}{l}-0.053 \\
(0.421)\end{array}$ & $\begin{array}{l}-0.416 \\
(0.514)\end{array}$ & $\begin{array}{l}-0.340 \\
(0.541)\end{array}$ \\
\hline Log per capital GDP & $\begin{array}{r}-1.227 * * \\
(0.131)\end{array}$ & $\begin{array}{l}-1.244 * * \\
(0.132)\end{array}$ & $\begin{array}{l}-1.246^{* *} \\
(0.143)\end{array}$ & $\begin{array}{r}-1.162^{* *} \\
(0.219)\end{array}$ & $\begin{array}{c}-1.254^{* *} \\
(0.223)\end{array}$ \\
\hline Ethno-linguistic fractionalization & $\begin{array}{l}-0.010 \\
(0.007)\end{array}$ & $\begin{array}{l}-0.061 \\
(0.066)\end{array}$ & & & \\
\hline $\begin{array}{l}\text { Ethno-linguistic fractionalization } \\
* \text { natural openness }\end{array}$ & & $\begin{array}{c}0.012 \\
(0.016)\end{array}$ & & & \\
\hline $\begin{array}{l}\text { Ethno-linguistic fractionalization } \\
* \text { residual openness }\end{array}$ & & $\begin{array}{c}0.007 \\
(0.009)\end{array}$ & & & \\
\hline Democracy & & & $\begin{array}{c}0.038 \\
(0.072)\end{array}$ & $\begin{array}{l}-0.024 \\
(0.108)\end{array}$ & $\begin{array}{l}-0.018 \\
(0.108)\end{array}$ \\
\hline Federalism & & & $\begin{array}{l}-0.043 \\
(0.463)\end{array}$ & & \\
\hline Decentralization (expenditure) & & & & $\begin{array}{c}-4.282^{* *} \\
(1.580)\end{array}$ & \\
\hline Decentralization (revenue) & & & & & $\begin{array}{c}-3.711^{* *} \\
(1.798)\end{array}$ \\
\hline R2 & 0.75 & 0.75 & 0.71 & 0.76 & 0.75 \\
\hline No. of Obs. & 70 & 70 & 80 & 51 & 51 \\
\hline
\end{tabular}




\section{Table 7: Natural Openness \& Public Sector Salaries}

\begin{tabular}{lccc}
\hline Dependent variable: public sector salary / manufacture wage \\
\hline \multicolumn{1}{l}{1} & 2 & 3 \\
Natural openness & & & \\
& $0.421^{*}$ & $0.438^{* *}$ & $0.316^{* *}$ \\
& $(0.226)$ & $(0.130)$ & $(0.154)$ \\
Residual openness & & $0.669^{* *}$ & $0.637^{* *}$ \\
& & $(0.194)$ & $(0.180)$ \\
Log per capital GDP & & & $0.219 * *$ \\
& & & $(0.076)$ \\
R2 & & & 0.11 \\
No. of Obs. & 29 & 29 & 29 \\
\hline
\end{tabular}

Note: Public sector relative salary on the left-hand-side is 1991 value (with four missing valued replaced by their 1990 values). All three variables on the right-hand-side are 1989 values. 


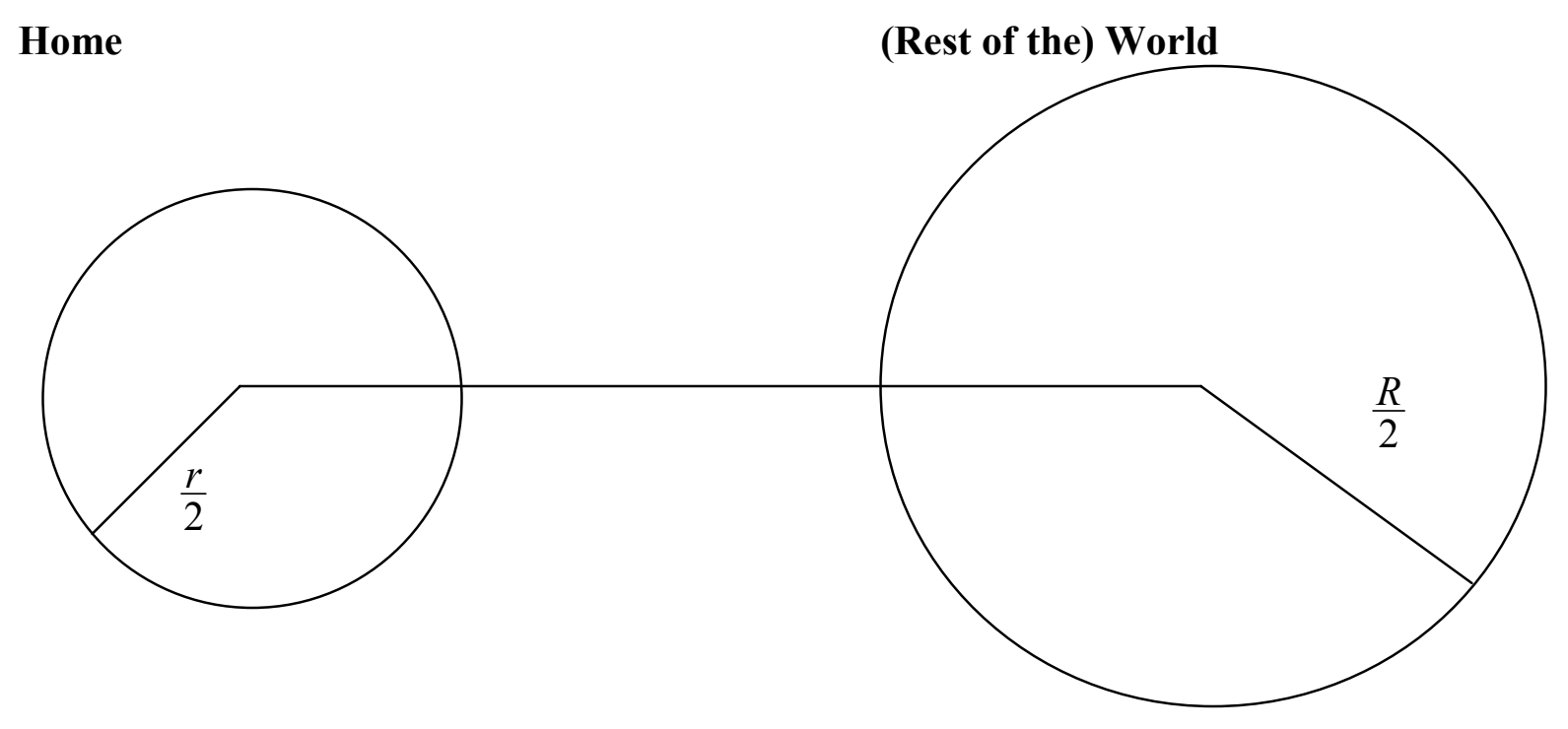

Figure 1: World Geography 